\title{
Public-Private Partnership as a Challenge for EAEU Cooperation
}

\author{
Shukhrat Safarov \\ $1^{\text {st }}$ year Postgraduate \\ Department "World economy and world finance" \\ Financial University under the Government of the Russian Federation \\ 49, Leningradsky Prospekt, Moscow \\ E-mail: 777safarov@gmail.com
}

\section{Supervisor: Irina Yarygina}

$\mathrm{PhD}$ in Economics, Professor at the Financial University under the Government of the Russian Federation

\begin{abstract}
In this article the author analyzes perspectives on the Eurasian Single Economic Space' concerning infrastructural investment projects. These perspectives are considered with a consideration of Public-Private Partnership (PPP) principles and the traditional framework of EAEU (Eurasian Economic Union) integration. The article examines national legal differences, such as the existence of regulations for PPPs, possible models for project realization and spheres where PPP could be used. The author also analyzes the characteristics of the most famous PPP projects in the EAEU.

The purpose of the article is to identify practical recommendations for the development of public-private partnerships to further cooperation between the EAEU countries.

This research stems from the study of international experiences of public-private partnerships, the adaptation thereof, and clarification of the necessary steps for the most efficient development of PPP in EAEU countries. As such, the following priority steps for EAEU countries are suggested:

1) EAEU countries should take steps to unite their respective legislative bases in terms of mutual compatibility so that public and private partners could act as inhabitants of the Union everywhere, removing not only customs barrier obstacles for them, but also additional tax restrictions;

2) EAEU countries should create an international council for problems and disputes pertaining to PPP which will include representatives of the countries of EAEU, representatives of the business and scientific communities and non-profit associations. Such a council was recommended to be set up at the United Nations during the third session of the United Nations Economic Commission for Europe on the problems of international public-private partnership, held in Geneva (Switzerland) on 18-19 April 2011;

3) EAEU countries should make use of practical experience in the implementation of interstate PPP projects. An example of a successful interstate PPP - the project for expansion and modernization of the international airport in Warsaw, through which more than $85 \%$ of all passengers of international flights have passed.
\end{abstract}

Keywords: EAEU, Public-Private Partnership, Eurasian integration, infrastructure investment

JEL: F02 
Recently, more and more researchers are promoting the idea that the CIS in its existing form is an unviable structure and there are very few prospects for its development. But, there is another structure, the prospects of which are brighter: the Eurasian Economic Union (hereinafter - the EAEU). The EAEU was established in 2015 based on the Eurasian Customs Union and the Single Economic Space. The EAEU includes the following countries: Russia, Kazakhstan, Armenia, Belarus and Kyrgyzstan. This union is highly supported by the population of this community. According to the Center for Integration Studies of the Eurasian Development Bank, 78\% of Russian respondents are in favor of the EAEU, $80 \%$ of respondents are in favor of EAEU in Kazakhstan, approximately $60 \%$ are in favor in Armenia and Belarus, and 86\% view the EAEU favorably in Kyrgyzstan [7].

In the EAEU countries, economic development is primarily characterized by the consolidation of efforts of the state and private business. There is, however a significant level of interest in exploring new forms and methods of managing and regulating strategically important spheres of the economy. Although the EAEU countries are increasingly beginning to consider public-private partnership (hereinafter - PPP) as a means to solve their infrastructural problems, the PPP is a new concept, and, accordingly, there is a lack of practical experience with this form of cooperation. The countries of the EAEU that are at the initial stages of developing national strategies for investment in infrastructural projects (including in the form of PPPs), need to expand understanding, deepen knowledge, develop integration capacity and develop international cooperation and coordination at the intergovernmental level in the field of PPPs. It will allow them properly develop and implement their PPP development strategies.

The purpose of this article is to identify practical recommendations on the development of public-private partnership for cooperation of the EAEU countries.

At present, the issue of economic interaction between private business and the state is becoming especially urgent. One of the most effective forms of such interaction is a public-private partnership that allows the state to implement socially significant projects by sharing costs and risks with private investors.

One of the main properties of an ideal regional economic integration model is the formation of an intra-union market of about 300 million people. This amount of population is enough to ensure a minimum stable domestic demand to support production. In 2015, the EAEU, with an aggregate population of 179 million people did not reach this level and fell behind comparably large economies such as the EU (511.4 million people), the USA (318.9 million people) and China (1 billion 355.7 million people).

Further enlargement of the EAEU due to the accession of new members from among the former Soviet countries is necessarily limited in quantitative terms. In the near future, Tajikistan is expected to enter the union with a population of 8 million, which is $4.5 \%$ of the population of the EAEU. The share of GDP in the all-union gross product is only $0.4 \%$, which is 2,700 US dollars (compared with average 12,155 US dollars in the EAEU). Uzbekistan is on a par, with a similar GDP, and its population is 28.9 million. When Tajikistan, Uzbekistan, Moldova and Azerbaijan accede to the EAEU, the Union's population will increase by as much as 84.9 million people to 263.8 million, which is already $88 \%$ of the necessary market of 300 million people.

Nowadays, in the EAEU countries, the problem of deterioration of the infrastructure is more acute than ever. That indicates the need to implement socially significant infrastructural projects, including developing the framework for public-private partnerships (PPP). The Eurasian Development Bank (EDB) has already been successful in implementing PPP projects in Russia, (namely the reconstruction of the only air harbor of the Northern Capital - Pulkovo Airport, as well as the construction of the "Western High Speed Diameter" highway). Now, the EDB are planning some strategic development towards increasing the share of the EAEU countries in the PPP market. In these cases, the EDB acts as a lending institution. In May 2016, a memorandum on cooperation on the development of PPPs in the member states of the EAEU was signed [9].

The Eurasian Development Bank sees the creation and development of joint projects in the field of infrastructure as a primary goal. But the creation of infrastructure is a capital-intensive and extremely long process. Meanwhile, international organizations such as the European Bank for Reconstruction and Development, the International Finance Corporation, the European Investment Bank, the United Nations Economic Commission for Europe, the World Bank (through PPIAF, WBI) are also actively involved in these processes. Involving a private investor is, definitionally, also an integral part of this process. The mechanism of public-private partnership is used for successful implementation of joint projects in the field of infrastructure with the participation of public and private partners [3].

The decision of the Supreme Economic Council of May 29, 2014, No. 70 "On the basic guidelines of the macroeconomic policy of the EAEU countries" was to continue working towards the development of PPPs, in respect of the legislative framework of the member states and regulation of PPP mechanisms [12].

An example of successful implementation is a large-scale project for the construction of an international transit corridor (the "Western Europe-Western China" corridor), which is planned to be completed in 2015 . It is $2700 \mathrm{~km}$, and it passes through Kazakhstan, as well as Russia and Belarus, (which in 2012 joined the implementation of this project) [11]. 
Table 1. Regulatory framework and institutions for PPP development in the countries of the Unified Energy System

\begin{tabular}{|c|c|}
\hline Rucsia & Republic \\
\hline
\end{tabular}

- The Law «On Concession Agreements»

- $\quad$ Draft Federal Law on PPP

- Draft procedure for conducting a competitive procedure for selecting a private partner

- Recommendations for the regions on PPP development

- Regional PPP standard. PPP development concept up to 2030 and PPP development roadmap

- Coordinating Council for PPP Development under the Ministry of Economic Development of Russia

- NP "Public-Private Partnership Development Center"
- The Law "On Concession Agreements"

- Draft law on public-private partnership

- The law "On objects that are only in the ownership of the state, and types of activities for implementation, which are subject to the exclusive right of the state"

- The Law "On creation of additional conditions for investment activity in the Republic of Belarus"

- State program "Strengthening of National Potential in Applying PPP Mechanisms in the Republic of Belarus"

- Center for PPP of the Research Economic Institute under the Ministry of Economy

- Interdepartmental Infrastructure Council, coordinating the development of infrastructure facilities
- The Law "On Concession Agreements"

- Rules for the provision, review and selection of facilities that are possible for transfer to a concession

- The rules for holding a tender for transferring an object to a concession

- Typical contracts of concessions in various sectors of the economy

- Draft law on public-private partnership

- The Program for the Development of Public-Private

Partnership in the Republic of Kazakhstan for 2011-2015.

- JSC "Kazakhstan Center for Public-Private Partnerships?
- The concept of public-private partnership, developed by the Yerevan office. The United Nations Development Program, is currently the only formally adopted document in the field of PPPs
- Law “On public-private partnership"

The Law "On Concessions and Concession Enterprises"

National Sustainable Development Strategy of the Kyrgyz Republic for the period 2013-2017. 
Table 2. The main barriers to the development of PPP in the countries of the Unified Energy System

\section{Russia}

Imperfect federal Russian legislation, oversights include the absence of state guarantees for

long-term state obligations

\section{Republic of Belarus}

There is no institutional basis for public-private partnerships
Republic of Kazakhstan

The lack of a law that defines the general principles of PPP, the framework conditions of agreements of economic entities with local government, executive authorities

\section{Armenia}

The concept of PPP, which took into account the most advanced world experience, which is currently the only officially accepted document in this field

\section{Kyrgyzstan}

There are no clear rules for the procedure for competitive selection of private partners
Absence of transparent and efficient procedures for selecting PPP projects
The system of interaction between Absence of necessary guarantees power structures and business within the framework of PPP has not yet been created to ensure full coverage of

investment and current costs of a private investor that has assumed the obligation to address these tasks
The rights and obligations of the parties to the partnership are not specified, the PPP project implementation models are not specified

$\begin{array}{ll}\text { The lack of enforcement } & \text { The change-of-leadership process } \\ \text { mechanisms and mechanisms for } & \text { in Kazakhstan itself is a barrier, } \\ \text { punishment in the event of non- } & \text { along with the lack of continuity } \\ \text { fulfillment by private partners of } & \text { in the executive branch and a } \\ \text { their contractual obligations } & \text { steady distrust of business and the } \\ \text { public to all institutions of power }\end{array}$


Despite the implementation of joint PPP projects by the EAEU countries, at present they are at different stages of implementation of the PPP model (Table 1). However, at the same time, the gap in the pace of PPP development is gradually widening among the EAEU countries. An analysis of PPP practices in the EAEU region makes it possible to identify obstacles to the better functioning of the market. The primary issues are: imperfect legislation, lack of an institutional framework for PPPs, lack of transparent and efficient procedures for selecting PPP projects, and lack of guarantees for investment, each of which are vital to ensure full coverage of the investment and current costs of a private investor (Table 2) [4].

As the table below shows, the uneven development of PPP in the EAEU countries is due to the practical lack of international cooperation and coordination between them at the interstate level.

On January 1, 2016, the federal Law "On public-private, municipal-private partnership in the Russian Federation" (henceforth referred to as the 'Federal Law on PPP of the Russian Federation') came into force. This federal Law was the cause of much contention among interested parties, but also undoubtedly opened a new page in the history of public-private partnership in Russia. At the same time, disputes still persist in the field.

\section{Private Sector participation in infrastructural projects in the Russian Federation (1990-2017yy.)}

It may not be deemed overly controversial to state as a generality that Russia's infrastructural projects have been known to fail rather often. Aside from this obvious disincentive for private parties to invest, Federal Law No. 115FZ of 21.07.2005 "On concession agreements" (henceforth referred to as "the Federal Law on concessions") facilitated implementation of one hundred separate projects. However, there is only one form of public-private partnership accommodated. Even a consolidation of the efforts of foreign investors would not allow the EAEU countries to access or utilize this and similar investment opportunities, especially since the idea of speaking on behalf of public partners from foreign countries does not require acknowledgement according to any of the applicable PPP Laws of the Russian Federation or the Federal Law on Concessions [2].

\section{Private Sector participation in infrastructural projects in Kazakhstan (1990-2014yy.)}

The relevant legislation of the Republic of Kazakhstan is noteworthy. This is primarily because the Law of the Republic of Kazakhstan of October 31, 2015 No. 379-V “On public-private partnership", (which came into effect later than the Federal Law "On PPP of the Russian Federation"), appears to be much more progressive. For example, it does not disregard the agency or interest of foreign private partners. It opens a list of facilities for the implementation of public-private partnership projects.

\section{Private Sector participation in infrastructural projects in Belarus (1990-2014yy.)}

At the moment, the Republic of Belarus is clearly lagging behind in the sphere of public-private partnership. At present, Belarus lacks special legislation on public-private partnership, where basic and necessary definitions would be given. On the other hand, some rules that relate to individual forms of public-private partnership are present in national legislation. For example, the investment code of the Republic of Belarus fixes provisions on concession agreements. However, it should be noted that in practice the use of the concession mechanism is virtually non-existent.

\section{Private Sector participation in infrastructural projects in the Kyrgyz Republic (1990-2014yy.)}

There is a special law in the Kyrgyz Republic - Law of the Kyrgyz Republic No. 7 of February 22, 2012 "On public-private partnership in the Kyrgyz Republic" which is appropriate for examination in the context of PPP. It is in fact, a good example of ineffective legislation. It is not structured in chapters- rather it includes 35 articles which provide several extremely general provisions. Thus, the Kyrgyz Republic also cannot boast of high-quality legislation in the sphere of public-private partnership [1].

\section{Private Sector participation in infrastructural projects in Armenia (1990-2016yy.)}

The Armenian legislation also does not regulate public-private partnership properly. The main types of PPP partnership in Armenia are trust management, leasing, concession, privatization of facilities and transfer of assets, and co-financing of infrastructure development projects. In general, to consider such types of partnerships as PPPs is not entirely accurate, although some researchers are inclined to do so [6].

As we can see from this brief overview of the legislation on public-private partnerships in the EAEU countries, the EAEU member states implement their own legislative activities, following their own principles and perceptions of public-private partnership. Thus, there cannot be a talk about joint PPP projects in interstate terms. Nevertheless, there exists a very qualitative and competent Model Law of the CIS "On Public-Private Partnership" written by a group of lawyers from St. Petersburg State University. The concept of the Model Law "On Public-Private Partnership" emphasizes that the best course of action is to adopt a general law on PPP (public-private partnership) and fix its concept, content, principles, subjects, objects and forms of PPP. The fact is that such a law can only be a framework. It cannot cover sufficient details of the legal regulation for each particular state. After all, the PPP concept represents extremely diverse forms of cooperation between the state and business: concession agreements 
and life-cycle contracts, production sharing agreements, leases with investment conditions, complex forms of contracts for the performance of works and services for public needs, trust management contracts, the establishment of business entities with mixed public-private participation, special economic zones, venture funds, and so on. Proposals for actual legislation on PPP would not only be required to outline the basis for regulating PPP, but will also detail regulatory legal requirements for various PPP facilities and entities, determine the permissible legal forms of implementation (the list of forms would ideally to be open to inspection, review, and potential development), the means of state regulation of PPPs and competitive procedures (e.g. tendering processes) for selecting a private partner [5].

It should be considered above all that due to the similarity of the technical and physical infrastructure, the management approaches of governments, the culture of the business communities, longstanding business relationships and the shared linguistic environment in the EAEU and CIS countries, it ought to be possible to effectively utilize PPPs to achieve higher levels of international cooperation in the context of the development of Eurasian integration.

Efforts to introduce approaches that would allow the EAEU countries to develop the PPP mechanism have been the subject of discussion among international organizations, most notably in the United Nations Economic Commission for Europe and the World Bank. [10] For example, the United Nations Economic Commission for Europe has outlined the following recommendations for developing the PPP mechanism in individual EAEU countries:

1) That institutional consideration should be given to studies regarding international experiences in the implementation of successful PPP projects;

2) That countries should create a dedicated Ministry or department which would be assigned responsibility for implementing the PPP mechanism;

3) That implementation of the PPP mechanism should be aimed toward the transition of the countries of the Eurasian space to the "green economy";

4) That the PPP department or Ministry should be prioritized by the respective Ministry of Economic Development by allocating additional resources, both human and financial, to ensure that this department best fulfills the role assigned to it, and so that the application of new knowledge around PPPs is encouraged in the implementation of sustainable infrastructure projects;

5) That the equal participation of the public sector and the private sector in creating new opportunities and active participation of the private sector in the delivery of public services is encouraged and incentivized.
The World Bank, for its part, made the following recommendations on the development of the PPP mechanism in the EAEU countries:

1) That the creation of favorable conditions for PPP, a clear policy on budgetary and financial support for PPPs and improvement of concessions and relevant legislation should be developed;

2) That development of a financial model for managing fiscal risks and monitoring contingent liabilities related to PPPs is necessary;

3) The creation of a centralized database of all objects for PPP;

4) The prioritization of viable projects based on convincing and robust financial models;

5) That the mitigation of risks taken by the participants should be given due consideration;

6) That the interests of all affected parties should be thoroughly considered.

As such, given the foregoing recommendations, and based on publicly available materials encouraging the use of the PPP as an instrument for promoting cooperation among the EAEU countries, it is seen to be necessary:

- To form a common terminology and principles of PPP in the EAEU countries;

- To create conditions for the application in the EAEU countries of a single list of PPP models;

- To conclude a tripartite cooperation agreement between the respective national PPP development centers (with the prospect of expansion);

- To take steps to unify the legislative base of the EAEU countries so that public and private partners can act as residents throughout the Union, removing not only customs barriers for them, but also additional tax restraints. It will promote economic integration and open additional opportunities for attracting extra budgetary finances and other resources in PPP projects in various infrastructure sectors in the EAEU countries;

- To form an international council on PPP problems, which will include representatives of the EAEU countries, the business and scientific community, and non-profit associations. Such a council (on international public-private partnerships) was recommended to be set up at the United Nations during the third session of the United Nations Economic Commission for Europe on the problems of international public-private partnership, held in Geneva (Switzerland) on 18-19 April 2011. One of the priority tasks in the work of the proposed council would be the development of the aforementioned model legislation on PPP and interstate economic cooperation; 
- To use practical experience in implementing interstate PPP projects. An example of a successful interstate PPP is the project for the expansion and modernization of the international airport in Warsaw, through which more than $85 \%$ of all passengers of international flights have passed;

In tandem with the foregoing, it must be considered that the 'new model' of globalization advanced by the USA forces us to look at the problem of international PPP in a new way. The president of the United States of America, Donald Trump, has allegedly considered the possibility of initiating of the United States' exit from the World Trade Organization (WTO). According to preliminary data, Trump does not fully understand the benefits of cooperation with the WTO. It has also been stated that Trump suspects that the organization is a means by which the rest of the world may try to manipulate the USA. It may be surmised that according to this example of Donald Trump's understanding, the process of globalization has ended, and that Washington is destined to drift into a 'trade war' with the European Union and China. According to this line of thought, in the nearest future the White House may be justified in raising import duties once again. What we have seen, as of February 2018, is that the USA did indeed raise import duties on Turkish goods. Additionally, Beijing has also expressed a protest in connection with the institution of new US import duties concerning Chinese goods. The authorities of China see this as an act which forces their hand, and are as such compelled (according to statement of the Ministry of commerce of the People's Republic of China) to institute their own counter measures in the form of similar duties. In this regard, China has introduced reciprocal $25 \%$ duties on imports of American goods to the amount of $\$ 16$ billion. Beijing has also expressed a protest in connection with these restrictive trade measures taken by Washington, and have expressed that they intend to initiate formal complaint procedures with the World Trade Organization. Experts have stated that the United States has indeed violated the rules of the WTO and are "waging economic war with the whole world". Analysts are convinced that an increase in duties will negatively affect growth rates of world trade and economy. However, it isn't exactly clear yet with whom Trump is struggling. Since March 23rd 2018, the United States has introduced duties on steel and aluminum production $-25 \%$ for steel and $10 \%$ for aluminum, which extend to all states which deliver production to the USA. However, the European Union countries, and also Australia, Argentina, Brazil, Canada, Mexico and the Republic of Korea received a delay on implementation for their imports until June 1st of 2018.

On foot of the measures taken by Washington, a number of states (including Russia, Canada, Mexico, Switzerland, India, Norway and some EU countries), have also initiated claims processes in the World Trade Organization. The US has even raised taxes on steel and aluminum which are imported to the USA from Canada and Mexico, the closest allies of the USA in the NAFTA group. The same rise in taxes has been implemented against steel and aluminum which is imported from EU countries, from Japan, South Korea, naturally, from Russia and China. In essence, it may be articulated that this increase in duties is indeed tantamount to economic warfare on all fronts, which may negatively affect the international status of globalization as a concept in itself, and international economic synergy in practice.

\section{Conclusion}

The preponderance of evidence suggests that the implementation of the recommended proposals outlined in this paper will help to lay the conceptual foundations of PPP mechanisms in the EAEU countries and will promote the development of international cooperation in the field of PPP and coordination between the EAEU countries at the interstate level. The coordinated policy and similar mechanisms for regulating the sphere of PPPs will allow for the creation of preconditions for in-depth cooperation between states that will remove barriers for foreign investors and entrepreneurs from the EAEU countries. This will enable competition between regional investors on PPP projects throughout the whole territory of the EAEU, thereby encouraging investment in social projects which will ensure the sustainable growth of business activity and a rise in the standard of living for the population.

The conclusions of the above research point towards the exceptional value of development of the mechanism of public-private partnerships. The results indicate that this is the most effective and readily-available instrument for the swift reorganization and modernization of the economy in the EAEU countries.

It can be seen that the state, in implementing projects with the use PPP mechanisms, will honor national interests and have the opportunity to control the implementation of socially significant projects. Meanwhile, private sector actors will similarly benefit from these projects not only financially, but also through developing experience of novel forms of project administration, resource management and strategic methodologies. Thus, the PPP is a strategic form of investment and may allow investors to achieve all the primary goals of their investment policies, including the profit motive, while also accommodating individual negotiation regarding the necessary conditions for investment.

It may be stated, finally, that the countries of the EAEU should consider all the nuances of adopting PPP models, including the possibility of decreased economic efficiency while the PPPs are not being utilized. On this point, it should be stressed that the potential benefits for removing the current barriers to foreign public and private investment through such models should be primarily considered with one eye upon those projects of great social importance that may be achieved. 


\section{References}

1. Investment Promotion Agency of the Ministry of Economy of the Kyrgyz Republic. URL: http://ppp.gov.kg/ en/news/full/13

2. Unified information system of public-private partnership in Russia. URL: http://www.pppi.ru/ (accessed 02.04.2016). (In Russ.).

3. EDB Integration barometer -2015 (fourth wave of survey). Analytical summary. St. Petersburg: Eurasian Development Bank; 2015. 46 p. URL: https://eabr.org/ upload/iblock/19f/edb_centre_report_33_analycal_ summary_eng.pdf

4. Eremin V.V., Mednikov A.A., Tsanava B.Z. Elements of a public-private partnership agreement under Federal Law No. 224-FZ of July 13, 2015 "On public-private partnership, municipal-private partnership in the Russian Federation". Otechestvennaya yurisprudentsiya $=$ National Law. 2016;(6): 48-50. URL: https://legalscience.ru/images/ PDF/2016/8/Otechestvennaja-jurisprudencija-6-8.pdf (In Russ.).

5. Belov S.A., Gritsenko E.V., Zhmulina D.A., et al. Publicprivate partnership in Russia and foreign countries: Legal aspects. Moscow: Infotropic Media; 2015. 528 p. (In Russ.).

6. Alipalo M., Chiplunkar A., Flor M. Yerevan water supply. Going private gradually: Armenia makes gains taking transitional route through private water. Manila: Asian Development Bank; 2008. 16 p. URL: https://www. adb.org/sites/default/files/publication/29276/yerevanwater.pdf

7. Evaluating the environment for public private partnerships in Asia-Pacific. The 2014 Infrascope. London: The Economist Intelligence Unit; 2015. 84 p. URL: https://www.adb.org/sites/default/files/ publication/158409/2014-infrascope.pdf
8. PPP Knowledge Lab. URL: https://pppknowledgelab. org/countries/kyrgyz-republic

9. Safarov Sh.A., Yarygina I.Z. Independent evaluation as a method for managing long-term investment risks. In: Scientific research and modern education. Proc. int. sci.-pract. conf. (Cheboksary, 29 April 2017). Cheboksary: SCC Interactive Plus; 2017: 294-304. URL: https:// interactive-plus.ru/e-articles/455/Action455-150602.pdf (In Russ.).

10. Public-private partnerships. The United Nations Economic Commission for Europe (UNECE). URL: https://www.unece.org/ceci/ppp.html

11. Decision of the Council of the Eurasian Economic Commission of July 20, 2012 No. 63 On the transport corridor "Western Europe - Western China" and the development of the transport and logistics potential of the Common Economic Space. URL: http://docs.cntd.ru/ document/902359451 (In Russ.).

12. Decision of the Supreme Eurasian Economic Council of May 29, 2014 No. 70 "On the main macroeconomic policy guidelines for the states-members of the Customs Union and the Common Economic Space for 2014-2015”. URL: https://www.alta.ru/tamdoc/14vr0070/ (In Russ.).

13. Country partnership strategy for the Republic of Kazakhstan for the period FY12FY17. March 30, 2012. Washington, DC: The World Bank; 2012.78 p. URL: http://documents. worldbank.org/curated/en/859761468272382244/ pdf/678760CAS0P1280Official0Use0Only090.pdf

14. Private participation in infrastructure database. The World Bank. URL: http://ppi.worldbank.org

15. UNECE PPP Assessment Report. Green PPPs in Kazakhstan. Geneva: United Nations Economic Commission for Europe; 2013. 48 p. URL: https://www. unece.org/fileadmin/DAM/ceci/documents/UNDA_ project/PPP_Readiness_Assessment_Kazakhstan.pdf 